\title{
Effect of autologous stem cells on regenerated bone during distraction osteogenesis by Ilizarov technique in the radius of dogs. Histomorphometric analysis ${ }^{1}$
}

\author{
Epitácio Leite Rolim FilhoI, Marcelo Correia de Araújo Larrazabal", Lauri Ferreira da Costa Júnior III, Saulo Monteiro dos \\ Santos ${ }^{\text {III }}$, Ricardo Monteiro dos Santos ${ }^{\text {IV }}$, José Lamartine de Andrade AguiarV \\ ${ }^{\mathrm{I}}$ Fellow PhD degree, Postgraduate Program in Surgery, Federal University of Pernambuco (UFPE), Recife-PE, Brazil. Conception and design of the \\ study, acquisition and interpretation of data, manuscript writing.

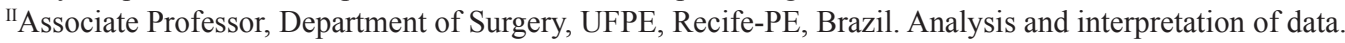 \\ IIIMaster, Department of Surgery, UFPE, Recife-PE, Brazil. Acquisition and interpretation of data, histomorphometric examinations. \\ ${ }^{\text {IV }}$ Graduate student, UFPE, Recife-PE, Brazil. Acquisition of data, helped with technical procedures and control of pre and postoperative of the animals. \\ ${ }^{v}$ Associate Professor, Postgraduate Program in Surgery, Department of Surgery, UFPE, Recife-PE, Brazil. Conception and design of the study.
}

\begin{abstract}
PURPOSE: To investigate by histomorphometry the distraction osteogenesis by Ilizarov technique in dog radius with the use of autologous stem cells in regenerated bone.

METHODS: Ten dogs (20 radiuses) underwent the osteotomy of 20\% of extension of their radiuses, and osteogenic distraction using the Ilizarov technique after this procedure at rate of $1 \mathrm{~mm}$ per day divided into $0.5 \mathrm{~mm}$ every 12 hours. The elongation was performed until the regeneration reached $20 \%$ of the total length of the radius. The stem cells were isolated, concentrated and injected in the regenerated bone, when it reached $10 \%$ of the length of the entire radius. The regenerated bone was evaluated using histomorphometric analysis when the elongation was $20 \%$ the size of radius.
\end{abstract}

RESULTS: The bone formation was evidenced by histomorphometric indices were significantly greater in the study group. In the histology evaluation the type of healing was mixed in $80 \%$ (intra membrane and endocondral) in both groups; the osteoblastic activity from moderate to intense was greater in the study group; and the space occupied by the newly-formed bone tissue was more evident in the study group.

CONCLUSIONS: The histomorphometric indices in this study expressing the microarchitecture, trabecular thickness, trabecular spacing, number of trabecula and quantity of bone that was significant in the group study. These data suggest that the use of undifferentiated stem cells autologous bone marrow in the regenerate bone induces osteogenesis and bone quality.

Key words: Ilizarov Technique. Osteogenesis, Distraction. Bone Regeneration. Stem Cells. Dogs. 


\section{Introduction}

The correction of faults and shortenings bone remains a complex problem and difficult to solve $e^{1-5}$, it requires longterm treatment, multiple surgeries, high complication rates and functional outcomes questionable $e^{1,6,7}$.

Ilizarov in 1951 revolutionized the treatment of musculoskeletal disorders through the concept of distraction osteogenesis using circular external fixator ${ }^{8-11}$. The technique uses biological and mechanical principles. After a corticotomy followed by slow and progressive distraction of the osteotomized bone segments, through a bone distractor generating a mechanical stress voltage at the fracture (osteotomy), which stimulates the formation of regenerated bone, and hence the growth of adjacent soft tissue, filling the space created by the osteotomy $y^{8,12}$.

Theoretically, there is no limit to the bone stretches by the Ilizarov technique ${ }^{4,9,10,13}$. However, one of the most limiting factors of this technique is the long-term required to consolidate the newly formed bone. This occurs mainly in large bone defects and shortening in that prolonged with the external fixator is associated with complications such as joint stiffness, subluxation or luxation, soft tissue contracture, infection, instability and loosening of the fixator pins or wires ${ }^{9}$

The autologous cancellous bone of the bone marrow is considered the best material for bone graft, not only for its osteoinductive and osteogenic properties, but also because it is not immunogenic, do not transmit infectious diseases and have lower cost of production ${ }^{14}$.

Nevertheless, the large bone defects, the required amount of autologous bone or the donor area morbidity prevents and limits its use $\mathrm{e}^{15,16}$. Aiming to replace or assist the autologous bone graft substitutes were devised, such as graft heterologous and homologous bioceramics, whose use revealed complications such as rejection, instability and infections ${ }^{17}$.

Studies aiming to improve the biological characteristics of bone allografts are described in the literature ${ }^{18,19}$. Among which is the enrichment of allograft with autologous bone marrow is rich in undifferentiated precursor cells osteoblasts ${ }^{20}$. Bone marrow stem cells have the potential to differentiate in cell lines involved in the repair of bone lesions. These cells play an important role in osteogenesis or phagocytosis, depending on the conditions of the medium ${ }^{21}$. However the use of autologous bone marrow is unable to fill large bone defects, and in those cases, associate it with grafts or bone substitutes ${ }^{10}$.

The treatment of large bone defects gained new strand at the end of last century and early this century, with the adjunctive use of stem cells obtained from bone marrow, growth factors plateletderived and bone morphogenetic proteins. These biological agents commonly are used in order to promote or accelerate the consolidation process or osteointegration, in association with bone grafts or substitutes, not as autologous grafts and bioceramics ${ }^{19}$.

The objective of this study was to analyse by histomorphometry the distraction osteogenesis by Ilizarov technique in dog radius using autologous stem cells in regenerated bone.

\section{Methods}

The project was approved by Ethics Committee on Animal Research, Federal University of Pernambuco (UFPE), $n^{\circ} 23076.020444 / 2008-49$. Experimental study accomplished in the Center for Experimental Surgery, UFPE, in the period from September 2006 to January 2008.

Twenty two radius of the right forearm and left 11 adult crossbred dogs were used, with weight varying from 15 to 20 $\mathrm{kg}$, average age of 4.5 years and clinically healthy. One dog was excluded from the study during the control procedure by failure of osteosynthesis material (breaking a Kirschner wire), compromising the regenerated bone during distraction osteogenesis phase.

The groups were formed by the forearms dogs (radius), determining by lot, which, for each dog, the group I (control) was constituted by the right forearm and the left as group II.

\section{Preoperative planning}

Panoramic radiographs in anteroposterior and lateral animal's forearm were performed before the surgery to determine the extention of osteotomy of $20 \%$, after the end of surgery and the every each seven day, for monitoring and to determine the total time of distraction osteogenesis (TTDO). It was assumed an elongation of $20 \%$ of the total length of the radius of each dog at the rate of $1 \mathrm{~mm} /$ day.

\section{Anesthetic and surgical procedures}

Anesthesia was induced with sodium pentobarbital (12.5 $\mathrm{mg} / \mathrm{kg}$ body weight) intravenously, following general anesthesia conducted with ketamine hydrochloride $(2.5 \mathrm{mg} / \mathrm{kg}$ body weight and pancuronium bromide $(0.1 \mathrm{mg} / \mathrm{kg}$ body weight $0.2 \mathrm{mg} / \mathrm{kg}$ body weight). The antibiotic prophylaxis was performed using the protocol of Rahal et al. ${ }^{7}$ The assembly of Ilizarov apparatus was composed of four rings of stainless steel $100 \mathrm{~mm}$ diameter, two on 
each end, connected by four threaded rods

The circular Ilizarov external apparatus was fixed at each end of the forearm bones, according to Ilizarov technique modified by Catagni et al. ${ }^{10}$. Then there was a transverse osteotomy at the diaphysis of the radius and ulna ${ }^{10}$.

\section{Postoperative procedures}

After seven days was initiated elongation of the bones in the forearm rate of $1 \mathrm{~mm} /$ day, divided into $0.5 \mathrm{~mm}$ every 12 hours.

In the control group, the distraction was carried out continuously until the regenerated obtain a length of $20 \%$ of the total size of the radius. In the study group at the time at which the same completed $10 \%$ of the total length of the radius, i.e., 50 $\%$ elongation provided the animal was prepared for collection of bone marrow and subsequent inoculation of autologous stem cells (TIC) within the regenerated bone.

\section{Stem cells procedures}

Bone marrow was collected by percutaneous puncture of the femoral medullary canal of the animal studied, internal condyle of the femur to the contralateral forearm previously operated. After puncture, proceeding to the aspiration of bone marrow $50 \mathrm{~mL}$ in a $60 \mathrm{~mL}$ syringe containing $10 \mathrm{~mL}$ of low molecular weight heparin.

The bone marrow aspirate was conducted to the laboratory for primary isolation and concentration of autologous stem cells. The concentrated CTI, volume of $2 \mathrm{~mL}$, was injected into the center of the regenerated bone through the left radius by Jelco 20-gauge.

After the consolidation of the bone segment lengthened the both, right and left radius, the animal underwent a new surgical procedure for resection in block of the regenerate bone, which was preserved in $10 \%$ formalin for preparation of histological slides with three cross-sections of $5 \mu \mathrm{m}$ thick, with respect to the longitudinal axis regenerated. The obtained sections were stained with hematoxylin and eosin (HE) and Masson Trichrome (TM) for histmorphometric study.

After collecting part (regenerated bone), the compression was performed at the site of bone defect using the same fixator. This was removed after clinical and radiographic pseudarthrosis site created previously. The animals were donated to institutions for animals.

\section{Histologic and morphometric procedures}

The capture of images for histomorphometric analysis was performed using a Motic digital cameras (Micro-Optic Industrial Group Ltd.COTM), attached to a Nikon microscope trinocular $^{\circledR}$, connected to a laptop computer. The histological images were processed and analyzed by morphometry program ImageJTM 1:42 version, with specific plug-ins.

The program Adobe Photoshop ${ }^{\mathrm{TM}}$ version CS4 Extended, Adobe $^{\mathrm{TM}}$, was used to assist the processing of images, as well as segmentation and selection of areas of interest with the histological mask tool, allowing the measurement of histomorphometric parameters.

Histomorphometry was analyzed using 10 fields (corresponding to $869.65 \mu \mathrm{m}$ per photo) in each histological section with $\mathrm{x} 10$ magnification, and 20 fields with $\mathrm{x} 40$ magnification.

The following histomorphometric indices were calculated: Percentage of new bone mineralized [TOTAr (\%)], Bone Volume [BV/TV (\%)], Trabecular Thickness [Tb.Th $(\mu \mathrm{m})]$, Number of Trabeculs [Tb.N (mm)], Trabecular Spacing [Tb.Sp $(\mu \mathrm{m})]$ and Osteoblastic Surface [Ob.S/BS (\%)]. The percentage of areas of fibrous tissue [FTAr $(\%)]$, cartilaginous tissue $[\mathrm{CgAr}(\%)]$, the total area of tissue [T.Ar(\%)], percentage of hypertrophic osteoblasts [OHT (\%)] and hyperplastic osteoblasts [OHP (\%)] were measured to assist in further histological evaluation ${ }^{22}$.

The type of bone, osteoblastic activity and proliferation of connective tissue areas were analyzed in the histological sections by optical microscopy with $\mathrm{x} 20, \mathrm{x} 40$ and $\mathrm{x} 100$ magnification. To classify the type of bone healing were evaluated 20 fields with x40 magnification in slides stained with T.M. were measured into account the percentage of $\operatorname{CgAr}(\%)$, FTAr (\%) relative to the analyzed total area $[\mathrm{T} . \operatorname{Ar}(\%)]$. In the type of bone joint was predominantly considered $\mathrm{OE}$, when the percentage area of the cartilaginous tissue was at least 5\% larger than the area of the membranous tissue. The types of osseous consolidation were considered: endochondral (OE), intramembranous (OI) and mixed (endochondral and intramembranous).

The evaluation of osteoblastic activity was performed by counting hypertrophic osteoblasts and hyperplastic osteoblasts (OHT) and total number of osteoblasts (OT), in 20 random fields with x100 magnification in slides stained with HE.

The osteoblastic activity was considered high when the sum of the percentage of OHP and OHT was greater than $50 \%$ of all osteoblasts sample; moderate activity, while the percentage of the sum of OHT and OHP was less than $50 \%$ and $10 \%$ greater; the low activity when the sum of the percentage of OHT and OHP 
was less than $10 \%$ of the total count of osteoblasts. The percentage occupancy of connective tissue, bone or not, was calculated with respect to the total area of the tissue [T.Ar.(\%)] of 20 random fields of stained slides with HE. The TAr took excellent consideration, and the percentage was equal to or greater than $90 \%$; good when less than $90 \%$ but equal to or greater than $50 \%$, regular, when less than $50 \%$ and equal to or greater than $10 \%$, and bad when T.Ar was less than $10 \%{ }^{22}$.

The histomorphometric data were stored directly in Microsoft Excel spreadsheets. As of quantitative variables (histomorphometric indices and healing time clinical and radiographic - TCCT) were expressed as mean and standard deviation (descriptive statistics). Test was used for statistical t-Student for paired samples. As qualitative variables (osteoblastic activity, occupation of newly formed tissue, bone and type of bone healing) were distributed in contingency tables. These variables were analyzed using Stuart-Maxwell nonparametric test.

The statistical program used was the Statistical Analysis System (SAS), version 8.0. The significance level for rejection or acceptance of the null hypothesis was $5.0 \%$.

\section{Results}

The total time of Clinical and radiographic healing (TCCR) of the regenerated bone in the control group varied from 62 to 155 days (mean of $117.4 \pm 28.0$ days), and in the study group ranged from 47 to 78 days (mean $64.3 \pm 8.2$ days) (Figure 1).

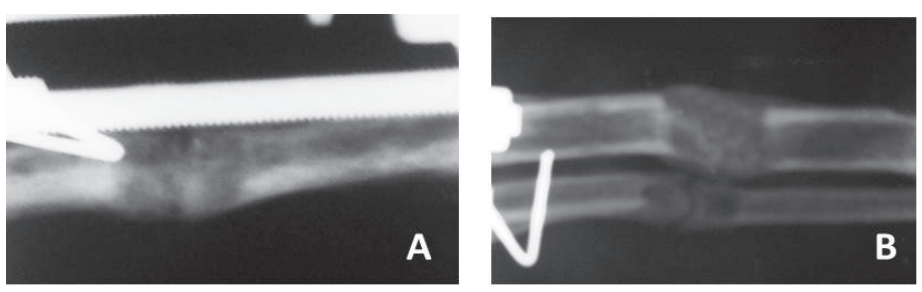

FIGURE 1 - Radiographs in AP two months after the osteotomy (A) and 43 days after inoculation of undifferentiated cells of bone marrow (B).

The average values of the indices related to histomorphometric number of trabecular [Tb.N (mm)], bone valume $[\mathrm{BV} / \mathrm{BT}(\%)]$, trabecular thickness [Tb.Th $(\mu \mathrm{m})]$, trabecular spacing [Tb.Sp $(\mu \mathrm{m})]$, and osteoblastic surface [SO $(\%)]$, the control and study groups are in the Table 1.

TABLE 1 - Histomorphometric rates of regenerate bone per groups.

\section{Groups}

\begin{tabular}{|c|c|c|c|c|c|}
\hline \multirow{2}{*}{ Histomorphometric Rates } & \multicolumn{2}{|c|}{ Control $(n=10)$} & \multicolumn{2}{|c|}{ Study $(n=10)$} & \multirow{2}{*}{$\mathbf{p}^{(1)}$} \\
\hline & Average & $\begin{array}{l}\text { Standard } \\
\text { deviation }\end{array}$ & Average & $\begin{array}{l}\text { Standard } \\
\text { deviation }\end{array}$ & \\
\hline $\begin{array}{l}\text { Number of trabeculae } \\
\quad[\text { Tb.N }(\mathrm{mm})]\end{array}$ & 6.86 & 1.97 & 14.30 & 4.86 & 0.0019 \\
\hline $\begin{array}{l}\text { Bone Volume } \\
{[\mathrm{BT} / \mathrm{TV}(\%)]}\end{array}$ & 36.23 & 12.16 & 59.18 & 5.63 & 0.0005 \\
\hline $\begin{array}{c}\text { Trabecular Thickness } \\
{[\operatorname{Tb} . T h(\mu \mathrm{m})]}\end{array}$ & 94.23 & 41.25 & 161.46 & 36.132 & 0.0116 \\
\hline Trabecular Spacing [Tb.Sp $(\mu \mathrm{m})]$ & 173.67 & 65.46 & 112.73 & 33.69 & 0.0231 \\
\hline Osteoblastic Surface (\%) & 42.31 & 18.13 & 70.52 & 16.24 & 0.0073 \\
\hline
\end{tabular}

Observation: ${ }^{(1)}$ Test $t$ of Student

The type of bone healing was similar in the control and study groups. In the control group, the type of endochondral ossification purely occurred in one $(10 \%)$ radio, intramembranous ossification, also in $1(10 \%)$ radio, and mixed ossification was seen in eight $(80 \%)$ radius (Table 2 , Figure 2$)$.

In the study group, there was one $(10 \%)$ radio with OI, one $(10 \%)$ case with $\mathrm{OE}$, and eight $(80 \%)$ radios with mixed ossification, among which three $(30 \%)$ had a prevalence of OI, three $(30 \%)$, predominance of OE. In the other two $(20 \%)$ radios, there was no predominance of one type of ossification on the other $(\mathrm{p}=0.9999)$. 
TABLE 2 - Distribution of the types of ossification of the regenerated bone in control and study groups.

\begin{tabular}{|c|c|c|c|c|}
\hline \multirow{3}{*}{ Type of Healing } & \multicolumn{4}{|c|}{ Groups } \\
\hline & \multicolumn{2}{|c|}{ Control $(n=10)$} & \multicolumn{2}{|c|}{ Study $(n=10)$} \\
\hline & $\mathrm{N}$ & $\%$ & $\mathrm{n}$ & $\%$ \\
\hline$O E$ & 1 & 10 & 1 & 10 \\
\hline$O I$ & 1 & 10 & 1 & 10 \\
\hline Prevalence of $O E$ & 2 & 20 & 3 & 30 \\
\hline Prevalence of $O I$ & 2 & 20 & 3 & 30 \\
\hline TOTAL & 10 & 100 & 10 & 100 \\
\hline $\mathrm{p}^{(1)}$ & \multicolumn{4}{|c|}{0.9999} \\
\hline
\end{tabular}

Observation: ${ }^{(1)}$ Stuart-Maxwell Test ${ }^{2}$

Legend: $\mathrm{OE}=$ endochondral ossification; $\mathrm{OI}=$ intramembranous ossification
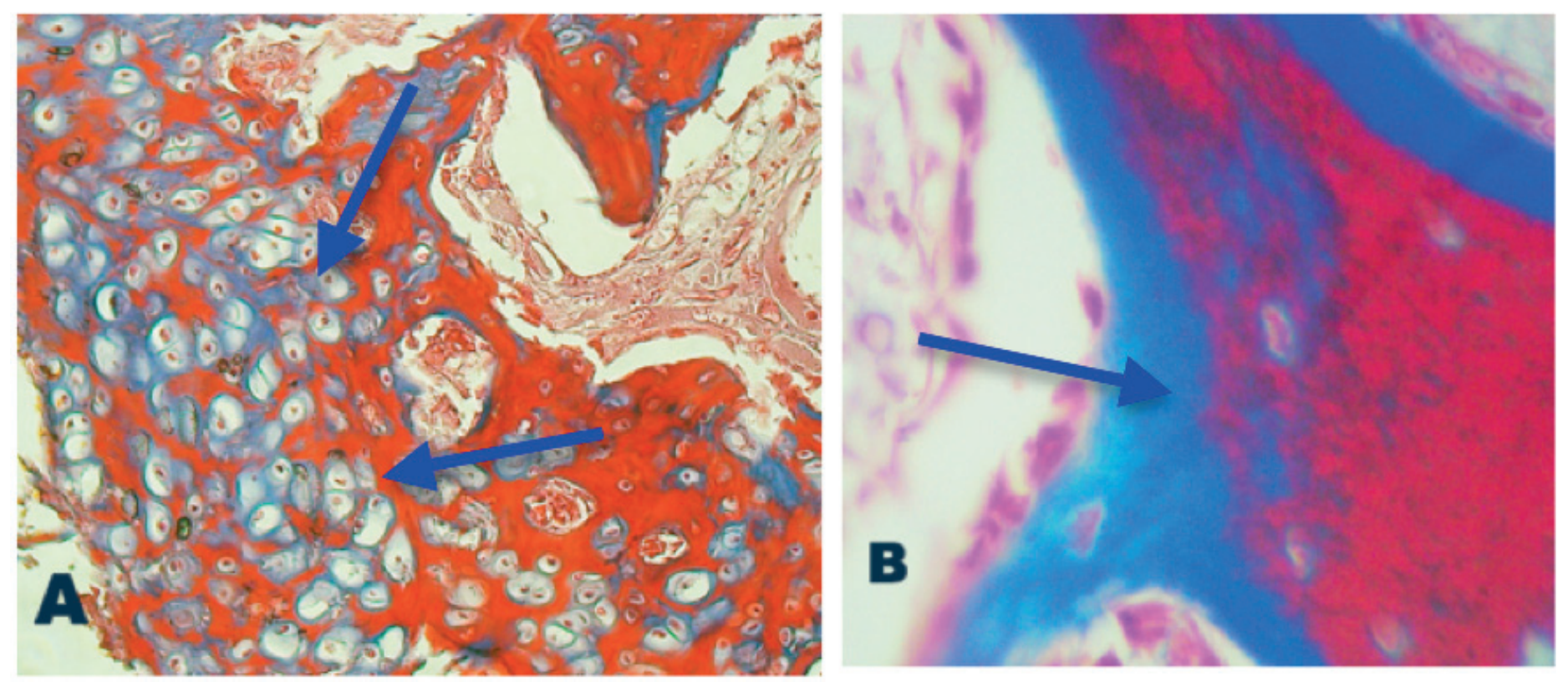

FIGURE 2 - Histological aspects of ossification. A. Endochondral. B. Intramembranous (x100).

The osteoblastic activity in all radios in the study group was distributed equally between moderate and high. In the control group, prevailed moderate osteoblastic activity, present in seven
(70\%) cases diagnosed as being high in one $(10 \%)$ cases, and poor in two $(20 \%)$ cases (Table 3, Figure 3). These differences in osteoblastic activity between the regenerated radius, control and study group were not significant $(p=0.9999)$.

TABLE 3 - Distribution of osteoblastic activity in bone regenerated radios in the control and study groups.

\begin{tabular}{ccccccc} 
& \multicolumn{3}{c}{ Groups } & \multicolumn{2}{c}{ Study (n=10) } & \multirow{2}{*}{$\mathbf{p}^{(1)}$} \\
\cline { 2 - 4 } Osteoblastic Activity & \multicolumn{2}{c}{ Control (n=10) } & $\mathrm{n}$ & $\%$ & \\
& $\mathrm{n}$ & 10 & 5 & 50 \\
\\
\cline { 2 - 5 } Higher & 1 & 70 & 5 & 50 & \\
Average & 7 & 20 & - & - & 0.9999 \\
Lower & 2 & 100 & 10 & 100 & \\
Total & 10 & & &
\end{tabular}

Observation:(1)Stuart-Maxwell Test 

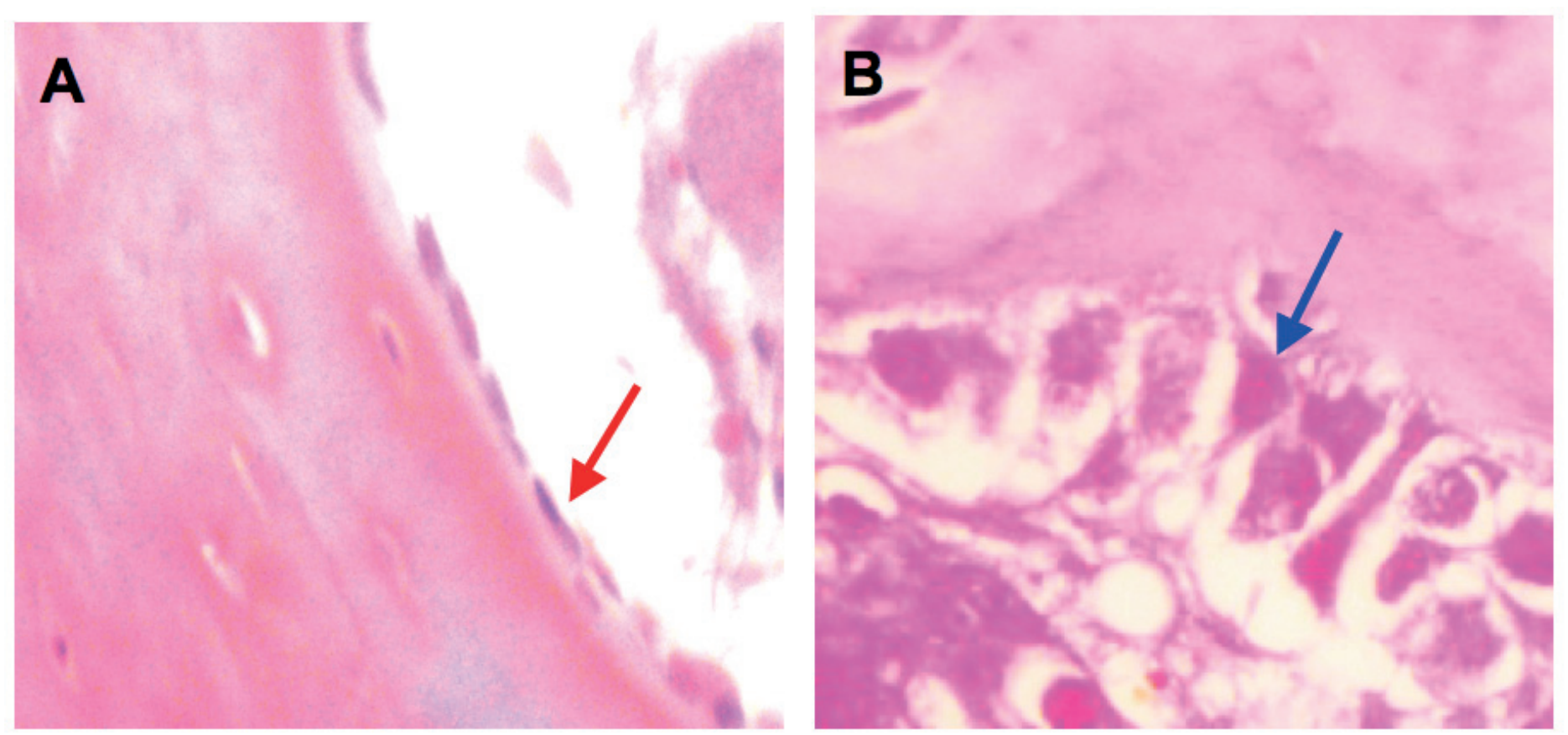

FIGURE 3 - Osteoblasts (x100 magnification - HE). A. Osteoblasts fusiform (red arrow). B. Osteoblasts hypertrophic/hyperplastic (blue arrow).

The percentage of the total area of the occupation in fields of histological tissue (bone and conective tussue) are described in Table 4.

TABLE 4 - Total area of occupancy of the fields by connective tissue in the control and study groups.

\begin{tabular}{|c|c|c|c|c|c|}
\hline \multirow{3}{*}{$\begin{array}{l}\text { Percentage of } \\
\text { total area of } \\
\text { occupancy }\end{array}$} & \multicolumn{4}{|c|}{ Groups } & \multirow{3}{*}{$\mathbf{p}^{(1)}$} \\
\hline & \multicolumn{2}{|c|}{ Control $(n=10)$} & \multicolumn{2}{|c|}{ Study $(n=10)$} & \\
\hline & n & $\%$ & n & $\%$ & \\
\hline$\geq 90$ & 4 & 40 & 7 & 70 & \\
\hline $50 \vdash 90$ & 4 & 40 & 3 & 30 & \\
\hline $10 \vdash 50$ & 1 & 10 & - & - & \\
\hline$\leq 10$ & 1 & 10 & - & - & \\
\hline Total & 10 & 100 & 10 & 100 & 0.705 \\
\hline
\end{tabular}

Observation: ${ }^{(1)}$ Stuart-Maxwell Test

In the control group, four radius, the percentage of occupation by bone and connective tissue, was greater than $90 \%$, in four radius was in the range of $50 \%$ to $90 \%$, in one $(10 \%)$ if the occupation was lower $50 \%$ and at one $(10 \%)$, less than $10 \%$. In the study group, the occupation with bone and other connective tissues exceeded $50 \%$ in the ten radius, among which seven (70\%) were occupied by more than $90 \%$ of the analyzed area and in three (30\%) radios, the occupation was between $50 \%$ and $90 \%$. In a significance level of $5 \%$, with no significant difference between groups $(\mathrm{p}=0.705)$.
In the observational study of the fields with respect to the histological type of tissue proliferated, it was found that areas not filled by bone tissue were occupied by fibro-cartilage, bone marrow or gaps still remained. The fibrous tissue and cartilage predominated in central regenerated. Only in a radius (control group) was observed a central area with significant amount of granulomatous tissue, rich in fibroblasts. There was no microscopic field with tissues or cells that characterize the infectious process, neoplastic, or teratogenic formation of heterotopic tissue areas analyzed. 


\section{Discussion}

Data from this study suggest that inoculation of undifferentiated cells of bone marrow can reduce the total time of consolidation of the regenerated bone during distraction osteogenesis by Ilizarov technique, and promote bone formation in greater quantity and quality, as evidenced by these data histomorphometric indices. Additionally, the technique is relatively safe as secondary infections and neoplastic degeneration. It was also observed that the greater the distraction frequency, the better the outcome ${ }^{8}$.

The histomorphometric rates (the number of trabecular per millimeter [Tb.N (mm)], bone volume [BV/BT (\%)], trabecular thickness [Tb.Th $(\mu \mathrm{m})]$, trabecular spacing [Tb.Sp $(\mu \mathrm{m})]$, the average percentage of osteoblastic surface [SO (\%)]), in the group that received the stem cells were higher of than in the control group. These differences were significants which demonstrates the effectiveness of undifferentiated cells of bone marrow as a factor that induces bone regeneration.

The histomorphometric rates for the number of trabecular per millimeter [Tb.N $(\mathrm{mm})]$ was higher $(14.3 \pm 4.86 \mathrm{~mm})$ and than in the control group $(6.9 \pm 2.0 \mathrm{~mm})$. This difference was on average $9.4 \mathrm{~mm}$ greater in the study, representing a significant difference $(p=0.0019)$ represents a good quality of the regenerated bone in the group treated with stem cells in the bone marrow.

The average value of bone volume [BV/BT (\%)] was lower in radius in the control group was $(36.2 \pm 12.2 \%)$ than and in the study group $(59.2 \pm 5.6 \%)$. The difference of $47.0 \%$ between these averages was significant $(\mathrm{p}=0.0005)$. Radius in the study group, the average of trabecular thickness [Tb.Th $(\mu \mathrm{m})]$ in the radius of the study group was higher $(161.4 \pm 36.1 \mu \mathrm{m})$ and than in the control group $(94.2 \pm 41.2 \mu \mathrm{m})$. The difference between these averages $(67.2 \mu \mathrm{m})$ was significant $(p=0.0116)$.

The average value of bone volume [BV/BT (\%)] was lower in radius in the control group it was $(36.2 \pm 12.2 \%)$ than in the study group $(59.2 \pm 5.6 \%)$. The difference of $47.0 \%$ between these averages was significant ( $p=0.0005$ as well as the average of trabecular thickness [Tb.Th $(\mu \mathrm{m})]$ in the radius of the study group was higher $(161.4 \pm 36.1 \mu \mathrm{m})$ than in the control group $(94.2 \pm$ $41.2 \mu \mathrm{m})$. The difference between these averages $(67.2 \mu \mathrm{m})$ was significant $(\mathrm{p}=0.0116)$. These results also indicate the effect of bone marrow stem cells as a factor inducing bone regeneration.

The average of trabecular spacing [Tb.Sp $(\mu \mathrm{m})$ ] in radius in the control group was $(173.67 \pm 65.46 \mu \mathrm{m})$ was higher than and in the study group $(112.73 \pm 33.69 \mu \mathrm{m})$. The difference of $60.94 \mu \mathrm{m}$ between these averages was significant $(\mathrm{p}=0.0231)$.
The average percentage of osteoblastic surface [SO (\%)] of the radius in the study group was $(70.52 \pm 16.24 \%)$ was higher than and in the control group $(42.31 \pm 18.13 \%)$. The difference between these averages of $28.21 \%$ was significant $(p=0.0073)$.

The average of trabecular spacing [Tb.Sp $(\mu \mathrm{m})]$ in radius of control group was $(173.67 \pm 65.46 \mu \mathrm{m})$ it was higher than and in the study group $(112.73 \pm 33.69 \mu \mathrm{m})$. The difference of 60.94 $\mu \mathrm{m}$ between these averages was significant $(\mathrm{p}=0.0231)$. The average percentage of osteoblastic surface $[\mathrm{SO}(\%)]$ of the radius in the study group was $(70.52 \pm 16.24 \%)$ was higher than and in the control group $(42.31 \pm 18.13 \%)$. The difference between these averages of $28.21 \%$ was significant $(p=0.0073)$.

All results from the methods applied in this study to assess bone regeneration indicated that the concentrated of autologous stem cells of bone marrow induces better quality of the regenerated in less time.

Comparing results this study with those of others in which the biological agent (stem cells obtained from bone marrow, growth factors platelet-derived and bone morphogenetic proteins) was introduced at the beginning or after the end of distraction osteogenesis, and the effects were similar ${ }^{19}$. Despite, this comparison should be made with care by the difference in methodology in relation to the biological agent used. The use of autologous undifferentiated stem cells promoted similar histological response to a cost-effective and less favorable.

In the present experiment, the type of consolidation was regenerated mixed (endochondral and intramembranous ossification) in $80 \%$ of radios in both the control group and the group study. There was no predominance of one type of ossification on the other $(\mathrm{p}=0.9999)$. The endochondral finding ossification during distraction osteogenesis were assigned by Ilizarov $^{8}$ to the frame instability of the fixator. However the findings of endochondral ossification in this study were not attributed to this factor, because we followed the biomechanical criteria followed in other experiments, which used similar settings ${ }^{2,4,6}$.

Fink et $a l .^{20}$, after histomorphometric studies of the type of ossification of the regenerate bone in distraction osteogenesis by Ilizarov technique that underwent 24 dogs, concluded that the formations endochondral and intramembranous occurred at a ratio of 5:1, and not were due to adverse situations as instabilities Ilizarov fixator ${ }^{19,20}$. Among the cases of mixed ossification, five cases occurred predominantly in one type of ossification, being three endochondral and two cases intramembranous. In the other three $(30 \%)$ radios, there was no predominance of one type of ossification over the other.

The autologous adult stem cells obtained from bone 
marrow have some advantages with respect to fetal stem cells, such as lower tumorogenecidade, technique of obtaining easier and less ethical problems ${ }^{23}$. This was confirmed in this experiment, since the regenerated bone in which the stem cells were introduced, there was no formation of heterotopic or neoplastic tissues. Moreover, the absence of histological features of these radios infectious process suggests that the techniques used to obtain, in the preparation and inoculation of these stem cells in regenerated bone during distraction osteogenesis are relatively safe.

The use of stem cells in large bone lesions tends to be a promising technique, associated with the techniques of bone distraction with external fixation, with high cost / benefit ratio, and can thus be incorporated in the routine treatment of orthopedic injuries.

\section{Conclusions}

The histomorphometric indices expressing the microarchitecture (trabecular thickness, trabecular spacing and number of trabecular) and quantity of bone were significant in the group study. These data suggest that the use of undifferentiated stem cells autologous bone marrow induces osteogenesis and bone quality.

\section{References}

1. Porto LCK, Fujiki EM, Ohara GH, Costa JEP, Fazoli PC, Mucciolo FMA. Tratamento pelo método Ilizarov. Análise das complicações e suas repercussões no objetivo proposto. Rev Bras Ortop. 1995;50(7):503-8

2. Rotbande I, Ramos, M, Hashimoto R, Rabelo GL, Carvalho ALC. Contribuição ao estudo biomecânico do aparelho de fixação externa de Ilizarov. Rev Bras Ortop, 1996;31(8):620-4.

3. Durigan Junior A, Batista LC. Corticotomia. Rev Bras Ortop. 1997;33(8):623-9.

4. Song HR, Cho SH, Koo KH, Jeong ST, Park YJ, Ko JH. Tibial bone defects treated by internal bone transport using the Ilizarov method. Inter Orthop. 1998;22(5):293-7.

5. Rotbande IS, Ramos MRF. Atualização em fixação externa: conceitos e revisão. Rev Bras Ortop. 2000;35(4):103-8.

6. Ramos M, Rotbande I, Ramos R, Gomes R, Carvalho JG, Santos LAVM. Tratamento das grandes falhas ósseas pelo método Ilizarov - Técnica trifocal. Rev Bras Ortop. 1999;34(4):255-9.

7. Rahal SC, Volpi RS, Iamaguti P, Ueda A. Avaliação histológica da regeneração óssea do rádio e ulna em cães submetidos ao alongamento com fixador de Ilizarov. Braz J Vet Res Anim Sci. 2001;38(3):122-6 .

8. Ilizarov GA. The tension-stress effect on the genesis and growth of tissues. Part I and II: the influence of stability of fixation and softtissue preservation. Clin Orthop. 1989;238(1):249-81.

9. Ilizarov GA. The principles of the Ilizarov method. J Dis Orthop Inst. 1988;48(1):1-11.

10. Catagni M, Bolano L, Cattaneo R. Management of fibular hemimelia using the Ilizarov method. Orthop Clin North Am. 1991;22(4):715-
22.

11. Prado I, Quirino A. Tratamento cirúrgico da pseudartrose não infectada da tíbia, pelo método Ilizarov. Rev Bras Ortop. 1999;34(6):369-74.

12. Aronson J, Harp JH. Mechanical forces as predictors of healing during tibial lengthening by distraction osteogenesis. Clin Orthop Relat Res. 1994;(301):73-9.

13. Catagni M, Felic J. Alongamento de dois níveis e o método de Ilizarov (trifocal) no tratamento da pseudartrose tibial com perda óssea. Rev Bras Ortop. 1996;31(8):613-9.

14. Hazra S, Song HR, Biswal S, Lee SH, Lee SH, Jang KM, Modi HN. Quantitative assessment of mineralization in distraction osteogenesis. Skeletal Radiol. 2008;37(9):843-7.

15. Lively MW. Sports medicine approach to low back pain. South Med J. 2002;95(6):642-6.

16. Kawano M, Taki J, Tsuchiya H, Tomita K, Tonami N. Predicting the outcome of distraction osteogenesis by 3-phase bone scintigraphy. J Nucl Med. 2003;44(3):369-74.

17. Zabeu JLA, Mercadante MT. Substitutos ósseos comparados ao enxerto ósseo autólogo em cirurgia ortopédica - Revisão sistemática da literatura. Rev Bras Ortop. 2008;43(3):59-68.

18. Lucarelli E, Fini M, Beccheroni A, Giavaresi G, Di Bella C, Aldini NN, Guzzardella G, Martini L, Cenacchi A, Di Maggio N, Sangiorgi L, Fornasari PM, Mercuri M, Giardino R, Donati D. Stromal stem cells and platelet-rich plasma improve bone allograft integration. Clin Ortop Relat Res. 2005;435(6):62-8.

19. Giordano V, Albuquerque RP, Rezende R, Senna LF, Pompei A, Amaral NP, Giordano M, Apfel MIR, Bastos JS. Estudo histomorfológico da incorporação de aloenxerto fresco e da hidroxiapatita de alta porosiade em defeito ósseo produzido em fêmures de ratos. Rev Bras Ortop. 2006;88(11):381-91.

20. Fink B, Pollnau C, Vogel M, Skripitz R, EnderleA. Histomorphometry of distraction osteogenesis during experimental tibial lengthening. J Orthop Trauma. 2003;17(2):113-8.

21. Burwell RG, The function of bone marrow in the incorporation of a bone graft. Clin Orthop. 1985;200(11):125-41.

22. Parfitt AM, Drezner MK, Glorieux FH, Kanis JA, Malluche H, Meunier PJ, Ott SM, Recker RR. Bone histomorphometry: standardization of nomenclature, symbols, and units. Report of the ASBMR Histomorphometry Nomenclature Committee. J Bone Miner Res. 1987;2(6):595-610.

23. Oliveira LAC, Sponchiado G, Adam MI. Conceitos e aplicações de células-tronco em medicina regenerativa: uma revisão. RUBS. 2006;2(2):32-42

\section{Correspondence:}

Epitácio Leite Rolim Filho

Hospital das Clínicas, Pós-Graduação em Cirurgia

Avenida Professor Moraes Rêgo, s/n - Bloco A

50670-420 Recife - PE Brasil

Tel.: (55 81)2126-8519

rolimfilho@uol.com.br

Received: April 19, 2013

Review: June 18, 2013

Accepted: July 22, 2013

Conflict of interest: none

Financial source: Coordination of Improvement for Higher Academic Staff (CAPES)

${ }^{1}$ Research performed at Center for Experimental Surgery, Federal University of Pernambuco (UFPE), Recife-PE, Brazil. Part of PhD degree thesis, Postgraduate Program in Surgery, UFPE. Tutor: Prof. Dr. José Lamartine de Andrade Aguiar. 